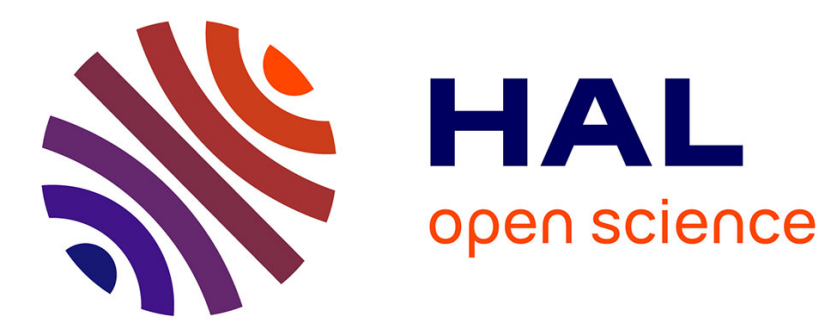

\title{
Book Review: Seelenmord und Psychiatrie - Zur Rehabilitierung Schrebers
}

Tilmann Habermas

\section{To cite this version:}

Tilmann Habermas. Book Review: Seelenmord und Psychiatrie - Zur Rehabilitierung Schrebers. History of Psychiatry, 2005, 16 (4), pp.509-510. 10.1177/0957154X0501600411 . hal-00570811

\section{HAL Id: hal-00570811 \\ https://hal.science/hal-00570811}

Submitted on 1 Mar 2011

HAL is a multi-disciplinary open access archive for the deposit and dissemination of scientific research documents, whether they are published or not. The documents may come from teaching and research institutions in France or abroad, or from public or private research centers.
L'archive ouverte pluridisciplinaire HAL, est destinée au dépôt et à la diffusion de documents scientifiques de niveau recherche, publiés ou non, émanant des établissements d'enseignement et de recherche français ou étrangers, des laboratoires publics ou privés. 
modern psychiatrist in a book which will be of interest to a broad range of specialists.

ELIZABETH LUNBECK Princeton University

\section{Zvi Lothane. Seelenmord und Psychiatrie - Zur Rehabilitierung} Schrebers. Gießen, Germany: Psychosozial Verlag, 2004. Pp. 668. ISBN 3-89806-242-2. €49.

Zvi Lothane's successful attempt to rehabilitate Paul Schreber (1842-1911) was published in English in 1992: In Defence of Schreber: Soul Murder and Psychiatry. The book has now been expanded and updated by the author, partially edited by Werner Felber and Hartmut Raguse, and translated into German. The original version was received as a well-researched, detailed account of Schreber's hospitalization and its historical context, and of the interpretations of his autobiographical account, Denkwürdigkeiten eines Nervenkranken (1903/2003).

This revised German translation differs from the American version, not in argument but in highlighting the central arguments, in additional detail, and in the updated literature on Schreber. The only chapter that has undergone a major expansion is the introduction. Here, Lothane helps the reader to find a way through the vast historical account in the following chapters by highlighting four myths which he intends to dismantle in the book: (1) that Freud first developed his theory of paranoia as being motivated as a defence against homosexual desires when interpreting Schreber's autobiographical monograph; (2) that Schreber merited the diagnosis of 'paranoia' (instead of depression); (3) that Schreber had a dominant homosexual orientation which would have motivated paranoia, instead of fears of homosexual attacks developing in the wake of an already evolving psychosis; (4) that Schreber's psychosis resulted from the allegedly sadistic pedagogy of his father, Moritz Schreber - an interpretation suggested by Niederland (1984). Historical details have been added in various chapters, such as precise biographical dates of Schreber's extended family and of his judicial career. The autopsy report has been added to the clinical notes. Sometimes references to other thinkers are added, for instance, when comparing some of Schreber's ideas with those of Martin Buber and Harry Stack Sullivan. Finally, the interesting chapter on interpretations of Schreber has been expanded, for example, by discussing in more detail Otto Gross's early reception of Schreber's book. Also, Lothane points out that Freud's interpretation of paranoia as a defence against homosexual fantasies predated his interpretation of Schreber and was translated into a correlation of manifest homosexuality and paranoia by many later psychoanalysts. 
The inclusion of quotes from letters and e-mails by contemporary psychoanalysts to the author is irritating, as are occasional lapses in the editing (e.g., 'style' is translated as 'aim' in the heading on p. 154, and there are some errors in syntax and publication date). Nevertheless, this book is recommended for those who missed the original version and are interested in how the history of interpretations of one text reflects the history of psychoanalytic and psychiatric thinking.

TILMANN HABERMAS

fohann Wolfgang Goethe Universität

Frankfurt a.M.

\section{References}

Lothane, Z. (1992) In Defence of Schreber: Soul Murder and Psychiatry (Hillsdale, NJ: Analytic Press).

Niederland, W. G. (1984). The Schreber Case: Psychoanalytic Profile of a Paranoid Personality (Hillsdale, NJ: Analytic Press).

Schreber, P. (1903) Denkwürdigkeiten eines Nervenkranken (Giessen, GE: Psychosozial Verlag, new edition, 2003).

\section{Acknowledgement}

The editor would like to thank the Members of the Advisory Board, the assistant editors and the many colleagues for their sterling help with the onerous task of refereeing the papers submitted to History of Psychiatry. It would be difficult to run the journal without their generous support. 